\title{
把持のロバスト性解析に基づくケージング拘束の定量的評価
}

\author{
牧 原 昂 志*1 槇 田諭*2
}

\section{Caging Quality Evaluation based on Analysis of Grasp Robustness}

\author{
Koshi Makihara*1 and Satoshi Makita*2
}

\begin{abstract}
This paper presents a novel measurement method for caging quality based on static analysis of robotic grasping and manipulation. Caging is a geometrical constraint of objects in which those captured by surrounding robots are restricted to move in the bounded space. The object constraint with some margin is a promising tool to allow uncertainties appearing in object perception and robot control. Because of limitation of robot configuration, complete caging that the object never escape from is, however, not accomplished sometimes, and the target object is partially caged. As for such partial caging, the quality of geometrical constraint has not been sufficiently evaluated. In this paper, we propose an evaluation index of the quality based on the robustness of grasping and manipulation in order to deal with both caging and mechanical constraint simultaneously. Some numerical results are presented to validate our proposed procedure of evaluation.
\end{abstract}

Key Words: Caging, Grasping, Manipulation, Static Analysis, Robustness

\section{1.は じめに}

ケージングとは対象物に対してロボットで形成した囲い(ケー ジ）の中に対象物を拘束し，その囲いから抜け出せないように運 動を制限する手法である [1]. 対象物の拘束のために物体の形状 を含む幾何情報のみが必要で, 位置制御ロボットによって物体を 拘束できる利点があり，把持姿勢のための pre-shaping として の拘束としても有用である $[2]$. このとき，対象物の幾何情報の 取得における不確かさや位置制御誤差などをある程度まで許容 して物体拘束を成立させることができる点も有用である，また， ケージング (囲い込み) が不完全な場合でも, 対象物の運動が阻 害されて，ロボットによる囲いから抜け出しにくくすることがで きる.これは partial cage [3] [4], パーシャルなケージングとよ ばれている. partial cage においては, 重力等の力学的作用まで 加味して対象物の抜け出しにくさを評価する energy-bounded caging [5] も提案されている.ケージングによる幾何学的な拘 束を考慮することは，把持，マニピュレーションの信頼性をさ らに高める作用が期待できる.

本論文では，マニピュレーションの静力学に基づいて，ケー ジング拘束の度合いを評価する手法を提案する．本手法では幾 何学的条件のみを考慮するケージングだけでなく, 力学条件も 加味するパーシャルなケージングも合わせて扱うことができる.

原稿受付 2019 年 2 月 15 日

*1 筑波大学大学院システム情報工学研究科

$* 2$ 福岡工業大学

${ }^{* 1}$ Graduate School of Systems and Information Engineering, University of Tsukuba

${ }^{* 2}$ Fukuoka Institute of Technology

ロ 本論文は新規性（要素分野）で評価されました。

ロ 本論文は第 24 回ロボティクスシンポジアの同時投稿オプションで投稿 されました。
なお，本論文におけるケージング拘束という呼称は，完全なケー ジングとパーシャルなケージングの両方を含むものとする.

Makapunyo らの partial cage の評価では, 物体の周囲に配 置されたロボットを障害物として, 無限遠点へ到達するまでの経 路計画問題を考えて, 経路の探索時間を評価指標とした[3] [4]. したがってここでは幾何条件のみを考慮しており, 力学的作用 は議論されていない，一方で，確率的探索ではあるが，脱出経 路が発見されなければ (実質的に) 完全なケージングであること も調べることができる. Mahler らの energy-bounded caging では対象物に対するパーシャルなケージングの状態において重 力等の外力が働いているとして, ロボットの囲い込みから脱出 するために必要なエネルギー量を拘束の評価指標とした [5]. こ のとき，ロボットの囲いから脱出したかどうかを定義しておく 必要がある。

筆者らは把持・マニピュレーションにおける接触力解析 [6] [7] を用いて，パーシャルなケージングを含むケージングの幾何学 的拘束の性能を評価する. 力学解析に基づくためパーシャルな ケージングにおける力学的作用による抜け出しにくさを文献 [5] 同様に評価できる.このとき, 文献 [7] で定義されるマニピュ レーションのロバスト性「外乱が加わっても対象物に対する把 持・操作が乱されないときの外乱力の最大值」を, ケージングに おける対象物の抜け出しにくさとする. そのため, Mahler ら [5] の解析のように, 障害物を迁回するような脱出については考慮 できない，本論文では一方向に対する平行移動，または回転運 動, すなわち Euclidean motion [8] での運動しにくさを評価す るものであることに留意されたい.

その一方で，力学拘束に基づく把持においても指配置による 幾何学的拘束の効果を同時に評価することができるので, 本論 文で提案する評価值によって, 力学的条件に基づいて幾何学的 拘束を考慮した指配置計画を導出できる，簡単な例として，二 


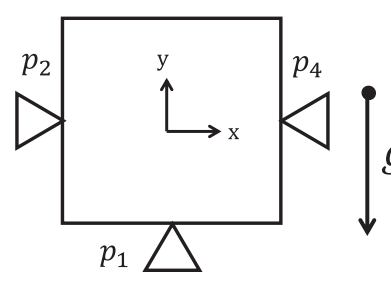

(a) Position a finger to oppose gravity

Fig. 1 Grasping by three-fingered hand in 2D space

次元空間での $y$ 方向への重力下の正方形物体の把握を考える (Fig. 1)。三指のロボットハンドを仮定し, Fig.1のような二 とおりの指配置パターンを与える。このとき把持のロバスト性 を評価すると，Fig. 1 (b) の配置よりも Fig. 1 (a)の配置のほう が，ロバスト性の評価值がより高い.Fig. 1 (b) の例では, 最 も外乱に弱い $-y$ 方向へは重力によって抜け出そうとする。一 方, Fig. 1 (a) の例では脱出可能な方向は $+y$ 方向には重力に逆 らって抜け出すための外力が必要になる。すなわち, 物体が運 動するために必要な外乱力の大きさがロバスト性の評価值を決 定する.

なお，いずれの場合においても指が配置される方向に対して は指から受ける接触力以上の外乱力を与えない限り, 把持が破 たんすること, 対象物が抜け出すことはない.もし, ロボット 指の関節トルクが無限大，すなわち位置制御指とすれば，この 方向のロバスト性の評価值は無限大となる。このようにロバス 卜性の評価值を用いることで，ロボット指による幾何学的拘束 を力学的拘束と同時に評価できると考える.

まとめると本論文では，これまで陽に評価されていなかった， 幾何学的拘束による運動しにくさと, 把持における力学的拘束 による対象物の運動しにくさの両方を同時に評価する指標を提 案する.これらは従来のマニピュレーションの力学解析におけ るロバスト性評価に基づく新たな解釈であり, 従来の把持の解 析に容易に適用可能である.

\section{2. 力学 モ デル}

本論文の力学モデルは梖田らの力学解析モデル [7] に基づい て，主要な式のみを抜粋して議論する，なお，本論文中で対象 物とロボットは静止状態にあるものとし，準静的な運動を含ま ない. また，以下の定式化は三次元空間の物体把持の問題を扱 うが，二次元空間の問題においても同様に適用可能である.

\section{1 仮定と記号の定義}

本論文の解析において, 対象物, ロボットの指, 環境はすべて 剛体であり, すべての接触は有限の摩擦あり点接触で近似でき るものとする. このとき, 各接触点ではクーロン摩擦が発生し, 接触点における各摩擦円すいは凸多角すいで近似する，ケージ ングにおいてロボット指は位置制御されるものとすることが多 いが，接触力解析において過大な内力の発生を引き起こすこと がある.そこで本論文ではロボット指は解析における便宜上, ハイブリッド制御されるものとする．ここでいうハイブリッド 制御とは直動関節と等価であり，ある一方向の押しつけ力のみ を能動的に制御可能で, そのほかの方向の接触力は受動的に決 定される. したがって, 各指の関節数 $L_{i}$ はすべて 1 となる.

- $N$ : 指の本数.

- $M_{i}: i$ 番めの指における接触点数.

- $M:=\sum_{i=1}^{N} M_{i}$ : 接触点数.
- $L_{i}=1: i$ 番めの指の関節数.

- $L:=\sum_{i=1}^{N} L_{i}=N$ : 指の総関節数.

- $P_{i k}: i$ 番めの指の $k$ 番めの接触点. 接触点には根元から昇 順に番号 $k$ をつける.

- $P_{l}$ : 全接触点の中の $l$ 番めの接触点. $l=\sum_{n=1}^{i-1} L_{n}+k$ と なるような通し番号をつける.

- $\boldsymbol{p}_{l} \in \mathbb{R}^{3}$ : 接触点 $P_{l}$ の位置.

- $\boldsymbol{t}_{l 1}, \boldsymbol{t}_{l 2} \in \mathbb{R}^{3}$ : 接触点 $P_{l}$ における接平面を張る正規直交基 底べクトル.

- $\boldsymbol{n}_{l} \in \mathbb{R}^{3}$ : 接触点 $P_{l}$ における対象物内向きの単位法線べク トル.

また，次の数学的表現を用いる.

・対角行列またはブロック対角行列： $\operatorname{diag}\left(\boldsymbol{A}_{1}, \ldots, \boldsymbol{A}_{n}\right):=\left[\begin{array}{lll}\boldsymbol{A}_{1} & & \boldsymbol{O} \\ & \ddots & \\ \boldsymbol{O} & & \boldsymbol{A}_{n}\end{array}\right]$

・ベクトルどうしの不等号： 二つのベクトル $\boldsymbol{a}:=\left[a_{1}, \ldots, a_{n}\right]^{T}, \boldsymbol{b}:=\left[b_{1}, \ldots, b_{n}\right]^{T}$ を 定義するとき, $\boldsymbol{a}>\boldsymbol{b}$ ならば， $a_{i}>b_{i},(i=1, \ldots, n)$ で ある。

\section{2 接触力}

接触点 $P_{l}$ で対象物に加わる接触力 $\boldsymbol{f}_{l} \in \mathbb{R}^{3}$ は,

$$
\boldsymbol{f}_{l}=\boldsymbol{C}_{l} \boldsymbol{k}_{l}
$$

ここで $\boldsymbol{C}_{l}:=\left[\boldsymbol{c}_{l 1}, \ldots, \boldsymbol{c}_{l r_{l}}\right] \in \mathbb{R}^{3 \times r_{l}}$ で, $\boldsymbol{c}_{l m}$ は接触点 $P_{l}$ の 摩擦円すいを凸多角すい近似した $m$ 番めの単位稜線ベクトル である. $\boldsymbol{k}_{l}:=\left[k_{l 1}, \ldots, k_{l r_{l}}\right]^{T} \in \mathbb{R}^{r_{l}}$ は接触力の大きさに対応 したべクトルであり， $\boldsymbol{k}_{l} \geq \mathbf{0}=[0, \ldots, 0]^{T}$ である.

指の接触点 $P_{i k}$ における接触力 $\boldsymbol{f}_{i k}$ と $i$ 番めの指の関節卜 ルク $\boldsymbol{\tau}_{i}$ の関係は次のように表される.

$$
\begin{gathered}
\boldsymbol{J}_{i k}^{T} \boldsymbol{f}_{i k}=\boldsymbol{\tau}_{i} \\
\boldsymbol{\tau}_{i}:=\left[\tau_{i 1}, \ldots, \tau_{i L_{i}}\right]^{T} \in \mathbb{R}^{L_{i}}
\end{gathered}
$$

ここで, $\boldsymbol{J}_{i k} \in \mathbb{R}^{3 \times L_{i}}$ は接触点 $P_{i k}$ に関するヤコビ行列, $\tau_{i j} \in \mathbb{R}^{1}$ は $i$ 番めの指の $j$ 番めの関節トルクである. 仮定 よりすべての指はハイブリッド制御され，関節数 1 の直動関節 に等価であるとすることから，

$$
\begin{gathered}
\boldsymbol{J}_{i k}=\boldsymbol{m}_{i} \in \mathbb{R}^{3}, \forall k \\
\boldsymbol{\tau}_{i}=\tau_{i 1}
\end{gathered}
$$

となる.ここで, $\boldsymbol{m}_{i}$ は $i$ 番めの指の関節運動の方向を表す単 位ベクトルである. また， $\tau_{i 1}=+\infty$ とすれば，位置制御指と みなせる。

ここで，以下の行列を定義する.

$$
\begin{gathered}
\boldsymbol{W}:=\left[\begin{array}{ccc}
\boldsymbol{I}_{3} & \ldots & \boldsymbol{I}_{3} \\
\boldsymbol{p}_{1} \times \boldsymbol{I}_{3} & \cdots & \boldsymbol{p}_{M} \times \boldsymbol{I}_{3}
\end{array}\right] \in \mathbb{R}^{6 \times 3 M} \\
\boldsymbol{C}:=\operatorname{diag}\left(\boldsymbol{C}_{1}, \ldots, \boldsymbol{C}_{M}\right) \in \mathbb{R}^{3 M \times r} \\
\boldsymbol{k}:=\left[\boldsymbol{k}_{1}^{T}, \ldots, \boldsymbol{k}_{M}^{T}\right]^{T} \in \mathbb{R}^{r} \\
\boldsymbol{T}:=\operatorname{diag}\left(\boldsymbol{T}_{1}, \ldots, \boldsymbol{T}_{M}\right) \in \mathbb{R}^{3 M \times 2 M} \\
\boldsymbol{T}_{l}:=\left[\boldsymbol{t}_{l 1} \boldsymbol{t}_{l 2}\right] \in \mathbb{R}^{3 \times 2} \\
\boldsymbol{J}:=\operatorname{diag}\left(\boldsymbol{J}_{1}, \ldots, \boldsymbol{J}_{N}\right) \in \mathbb{R}^{3 M \times L} \\
\boldsymbol{J}_{i}:=\left[\boldsymbol{J}_{i 1}^{T}, \ldots, \boldsymbol{J}_{i M_{i}}^{T}\right]^{T} \in \mathbb{R}^{3 M_{i} \times L_{i}}
\end{gathered}
$$




$$
\begin{aligned}
\boldsymbol{f} & :=\left[\boldsymbol{f}_{1}^{T}, \ldots, \boldsymbol{f}_{M}^{T}\right]^{T} \in \mathbb{R}^{3 M} \\
\boldsymbol{\tau} & :=\left[\boldsymbol{\tau}_{1}^{T}, \ldots, \boldsymbol{\tau}_{N}^{T}\right]^{T} \in \mathbb{R}^{L}
\end{aligned}
$$

$\boldsymbol{I}_{n}$ は $n \times n$ の単位行列, $\boldsymbol{p}_{l} \times \boldsymbol{I}_{3} \in \mathbb{R}^{3 \times 3}$ は $\left(\boldsymbol{p}_{l} \times \boldsymbol{I}_{3}\right) \boldsymbol{x} \equiv \boldsymbol{p}_{l} \times \boldsymbol{x}$ となる外積と等価な歪対称行列を表す.

以上の定義から，すべての接触力は，

$$
f=C k
$$

と書ける。したがって，摩擦力は，

$$
\boldsymbol{T}^{T} \boldsymbol{f}=\boldsymbol{T}^{T} \boldsymbol{C k} \in \mathbb{R}^{2 M}
$$

と書ける.

ここで, 静止摩擦力の制約条件 [7] を考慮すると, 発生可能な 静止摩擦力の組み合わせは次の式を満たす必要がある.

$$
\begin{gathered}
\boldsymbol{S} \boldsymbol{T}^{T} \boldsymbol{C k} \leq \mathbf{0} \\
\boldsymbol{T}^{T}\left(\boldsymbol{I}_{3 M}-\boldsymbol{B}\right) \boldsymbol{C k}=\mathbf{0} .
\end{gathered}
$$

$\boldsymbol{S}:=\operatorname{diag}\left(s_{11}, s_{12}, s_{21}, s_{22}, \ldots, s_{M 1}, s_{M 2}\right) \in \mathbb{R}^{2 M \times 2 M}$ は各接 触点での静止摩擦力を発生させうる微小変位（せん断ひ ずみ）の方向の符号を表し， $s_{l m}=\{ \pm 1,0\}$ をとる. $\boldsymbol{B}:=\operatorname{diag}\left(b_{1} \boldsymbol{I}_{3}, \ldots, b_{M} \boldsymbol{I}_{3}\right) \in \mathbb{R}^{3 M \times 3 M}$ は接触点において微 小変位が生じるかどうかを選択する行列で，対象物全体の微小 運動の結果として接触点 $P_{l}$ で微小変位が起こる場合は $b_{l}=1$, それ以外の場合は $b_{l}=0$ をとる. したがって， $b_{l}=0$ のとき必 ず $s_{l m}=0$ である. 式 (17) は接触点での微小変位の方向（符 号）と接触力の方向 (符号) が逆向きになることを表す。また, 式（18）は微小変位の生じない接触点で静止摩擦力が生じない ことを表す。

式（17）の微小変位の組み合わせが発生可能なものであるか どうかは次の線形計画問題を解くことで判定できる.

$$
\text { subject to }\left\{\begin{array}{l}
\operatorname{maximize}_{\boldsymbol{q}, \boldsymbol{V}, \dot{\boldsymbol{\theta}}} \mathbf{1}^{T} \boldsymbol{q} \\
\boldsymbol{B}\left[\begin{array}{ll}
\boldsymbol{W}^{T} & \boldsymbol{J}
\end{array}\right]\left[\begin{array}{c}
\boldsymbol{V} \\
-\dot{\boldsymbol{\theta}}
\end{array}\right]=\boldsymbol{T} \boldsymbol{S} \boldsymbol{q}
\end{array}\right.
$$

ここで， $\mathbf{1}=[1, \ldots, 1]^{T}$ である，なお，式（19）を満たす $\boldsymbol{q}$ が 存在するとき, 評価関数は無限大になる。このことから, 実際 の制約条件は $\boldsymbol{q} \geq \mathbf{0}$ であるが, $\boldsymbol{q} \geq \mathbf{1}$ としても一般性を失わ ない.

接触力と関節トルクの関係は,

$$
\boldsymbol{J}^{T} \boldsymbol{f}=\boldsymbol{J}^{T} \boldsymbol{C k}=\boldsymbol{\tau}
$$

と書ける.

対象物の静的なつりあいの式は，重力などの対象物に加わる 既知の外力および外モーメントを $\boldsymbol{Q}_{\text {known }} \in \mathbb{R}^{6}$, 未知の外力お よび外モーメントを $\boldsymbol{Q}_{\mathrm{dist}} \in \mathbb{R}^{6}$ として，次のように表す。

$$
\boldsymbol{W} \boldsymbol{f}=\boldsymbol{W} \boldsymbol{C} \boldsymbol{k}=-\left(\boldsymbol{Q}_{\mathrm{known}}+\boldsymbol{Q}_{\mathrm{dist}}\right)
$$

\section{3 物体操作のロバスト性評価}

物体操作のロバスト性の評価手法は Maeda ら [9] の提案した 「操作中の対象物が未知の外乱力に対してどの程度まで耐えるこ
とができるか（操作を乱されないか）を定量的に評価する指標」 を採用する．本論文ではこれに操作のロバスト性の評価值 $z$ を 文献 [7]に基づいて, 以下の線形計画問題群から成るミニマック ス問題から計算する.

$$
\begin{gathered}
\quad z=\min _{i} z_{i} \\
z_{i}=\max _{\zeta, \boldsymbol{k}, \boldsymbol{B}, \boldsymbol{S}, \boldsymbol{\tau}} \zeta \\
\text { subject to }\left\{\begin{array}{l}
\zeta\left(\boldsymbol{R}^{1 / 2}\right)^{-1} \boldsymbol{l}_{i}+\boldsymbol{Q}_{\text {known }}+\boldsymbol{W} \boldsymbol{C} \boldsymbol{k}=\mathbf{0} \\
\boldsymbol{J}^{T} \boldsymbol{C} \boldsymbol{k}-\boldsymbol{\tau}=\mathbf{0} \\
\boldsymbol{T}^{T}\left(\boldsymbol{I}_{3 M}-\boldsymbol{B}\right) \boldsymbol{C k}=\mathbf{0} \\
\boldsymbol{S} \boldsymbol{T}^{T} \boldsymbol{C} \boldsymbol{k} \leq \mathbf{0} \\
\mathbf{0} \leq \boldsymbol{\tau} \leq \tau_{\max } \mathbf{1} \\
\boldsymbol{k} \geq \mathbf{0} \\
\zeta \geq 0
\end{array}\right.
\end{gathered}
$$

ここで, $\tau_{\max }$ は関節トルクの上限值を表す． $\boldsymbol{R}^{1 / 2} \in \mathbb{R}^{6 \times 6}$ は行 列 $\boldsymbol{R} \in \mathbb{R}^{6 \times 6}$ を Cholesky 分解したものであり， $\boldsymbol{R}$ は力とモー メントの両方を同時に扱うためにスケーリングを行う正定值対 称行列である.ここでは, 対象物の質量 $M_{0}$ と対象物の重心に対 する慣性テンソル $\boldsymbol{J}_{0} \in \mathbb{R}^{3 \times 3}$ を用いて $\boldsymbol{R}:=\left[\begin{array}{cc}\boldsymbol{I}_{3} & \boldsymbol{O} \\ \boldsymbol{O} & M_{0} \boldsymbol{J}_{0}^{-1}\end{array}\right]$ と定義する. $\boldsymbol{l}_{i} \in \mathbb{R}^{6}$ は未知の外力. 外モーメント $\boldsymbol{Q}_{\mathrm{dist}}$ が働 く方向を表す. 式（23）ではある方向から対象物に働く外力. 外モーメントが物体操作を乱さない範囲で取りうる最大值を求 める．想定される $\boldsymbol{Q}_{\mathrm{dist}}$ は任意の方向を取りうるが，非線形条 件となるため, 有限数の $\boldsymbol{l}_{i}$ を考える. 式 $(22)$ は物体操作が乱 されやすい, 外力・外モーメントに最も弱い方向を求める.

\section{4 操作のロバスト性に基づくケージング拘束の評価}

式 (22)，（23）で計算される物体操作のロバスト性に基づい て，ケージング拘束を評価する。ケージングによって対象物を 拘束するロボット指は多くの場合, 幾何学的な指配置のために 位置制御されるものとみなされる，ただし，本論文で採用する 剛体の力学モデルに基づくロバスト性解析では，例えば位置制 御指でピンチング把持をする場合などに過大な内力を導くこと がある，そのため，本論文では便宜上，すべての指をハイブリッ ド制御として過大な内力の発生が算出されないようにした。接 触力解析の結果, force closure となる接触力の組が解として求 まることはあるが，ケージング拘束においては必ずしも force closure が成立するとは限らない.

ある把持状態において六次元空間の方向に外力・外モーメン トが加わったときに，ロボット指からの接触力や，重力などの既 知の外力によってある程度までそれに耐えることができる。ロ バスト性の上限值の外力・外モーメントが対象物に働いたとき, 対象物への力のつり合いは破綻し, 対象物は運動を始める。し たがって, 本論文において物体操作のロバスト性は, その把握さ れる対象物がある方向へどの程度, 運動しにくいか，を表す指標 である。このときの運動は瞬間的に見れば Euclidean motion であり，単一の並進運動または単一の回転運動，およびそれら の複合運動に等価である. 例えば Fig. 1 (a) のような指配置の とき, ロボット指が存在する方向 $(+x$ 方向など $)$ への並進運 動は指から受ける接触力よりも大きな外力を与えない限り運動 することはない.したがって, 動かない剛体の環境と等価とみ なせる位置制御指の場合には, 対象物がその方向へ運動するこ 
とは不可能である.つまり, ロボット指の囲い込みによって幾 何学的に拘束されていることは，その方向へのロバスト性が上 限值に到達することで判定できる.

一方，対象物が脱出可能な方向については，重力など既知の 外力や，ロボット指からの接触力を受けて対象物が運動しにく ければ，相応のロバスト性が評価される。したがって，幾何学 的な拘束が不完全な場合であっても，その方向への力学的作用 による抜け出しにくさを定量的に評価できる.

\section{3. 数 值 計 算 例}

\section{1 計算条件}

本論文では二次元の把持について，把持のロバスト性の評価 手法に基づいて，ケージング拘束の評価手法の有効性を議論す る. 前提条件として，以下のように各パラメータを設定する.

・座標原点は対象物の重心とする.

- 対象物の質量は 1 とし $\left(M_{0}=1\right)$, 質量分布は一様である.

・静止摩擦係数は 0.3 とする.

本論文では二次元空間，すなわち三次元コンフィグレーション 空間での外力の代表的な方向を表すべクトルとして， $l_{i}$ を次の 14 方向にとった。 なお，ベクトル内の複合はすべての組み合わ せをとる。

$\boldsymbol{l}_{i}=\left\{[ \pm 1,0,0]^{T},[0, \pm 1,0]^{T},[0,0, \pm 1]^{T}, \frac{1}{\sqrt{3}}[ \pm 1, \pm 1, \pm 1]^{T}\right\}$ 既知の外力としての重力は $\boldsymbol{Q}_{\text {known }}=[0,-9.8,0]^{T}$, 関節卜 ルクの上限值は $\tau_{\max }=40.0$ と設定する.

\section{2 正方形物体のケージング把持}

Fig. 1，2 で与えられる正方形物体の把持のロバスト性を解析 する．指の位置は Fig. 2 (e) で与えられた四つの接触点を基準 とし， $p_{1}, \ldots, p_{4}$ までの指配置を変化させる，各パラメー夕は 以下のように設定する.

$$
\begin{aligned}
& \boldsymbol{p}_{1}=\left[\begin{array}{c}
0.0 \\
-1.0
\end{array}\right], \boldsymbol{p}_{2}=\left[\begin{array}{c}
-1.0 \\
0.0
\end{array}\right], \boldsymbol{p}_{3}=\left[\begin{array}{l}
0.0 \\
1.0
\end{array}\right], \boldsymbol{p}_{4}=\left[\begin{array}{c}
1.0 \\
0.0
\end{array}\right] \text {, } \\
& \boldsymbol{T}_{1}=\left[\begin{array}{l}
1 \\
0
\end{array}\right], \quad \boldsymbol{T}_{2}=\left[\begin{array}{l}
0 \\
1
\end{array}\right], \quad \boldsymbol{T}_{3}=\left[\begin{array}{l}
1 \\
0
\end{array}\right], \quad \boldsymbol{T}_{4}=\left[\begin{array}{l}
0 \\
1
\end{array}\right], \\
& \boldsymbol{N}_{1}=\left[\begin{array}{l}
0 \\
1
\end{array}\right], \quad \boldsymbol{N}_{2}=\left[\begin{array}{l}
1 \\
0
\end{array}\right], \quad \boldsymbol{N}_{3}=\left[\begin{array}{c}
0 \\
-1
\end{array}\right], \quad \boldsymbol{N}_{4}=\left[\begin{array}{c}
-1 \\
0
\end{array}\right], \\
& \boldsymbol{J}_{1}=\boldsymbol{N}_{1}, \quad \boldsymbol{J}_{2}=\boldsymbol{N}_{2}, \quad \boldsymbol{J}_{3}=\boldsymbol{N}_{3}, \quad \boldsymbol{J}_{4}=\boldsymbol{N}_{4}
\end{aligned}
$$

解析の結果で得られた指配置のロバスト性の最小值を Table 1 に示す。二指ハンドの把持では Fig. 2 (b) の評価值が高く，重 力に対抗するように指配置をしていることが理由に挙げられる. 三指ハンドでの把持の例ではFig. 1 (a) の評価值が最も高く, 第 1 章終わりで述べたように，重力に対抗するようなロボット指か らの接触力を発揮しやすい指配置・把持姿勢にすることで，ロバ スト性をより高めることが結果から分かる．Fig. 2 (e)の場合が すべての配置の中で最も高いロバスト性を示すことは明らかであ る。この指配置は実質的には完全なケージングとなっているの で，位置制御指であれば全方向の外力に対して無限大のロバスト 性を発揮することができる。また，Fig. 1 (b) と Fig. 2 (a) では 同一の評価值となっているが, 幾何学的観点からでは, Fig. 1 (b) の場合がより抜け出しにくいといえる。 そこで各方向に対する ロバスト性の総和をとると, Fig. 1 (b) では 404.6, Fig. 2 (a) で は 290.5 の結果となった。このことから，外力の各方向に対す るロバスト性の総和をとることによっても評価が可能である.

なお， $l_{i}$ の方向はより多くを設定して計算することで，さら に精緻な解析が可能であるが，ここでは上記のような特徵的な 傾向を比較することに注目した.

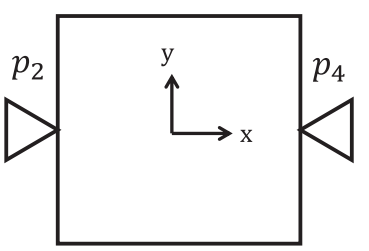

(a) Pinching by two-finger (parallel to $\mathrm{x}$ axis)

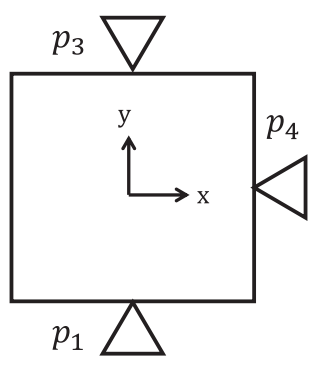

(c) Grasping by three-finger (a finger locates on the right side)

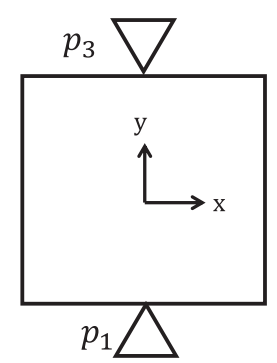

(b) Pinching by two-finger (parallel to y axis)

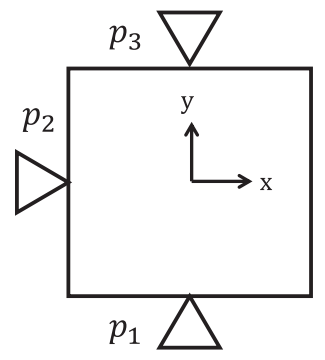

(d) Grasping by three-finger (a finger locates on the left side)

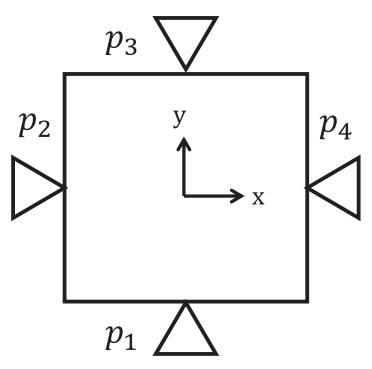

(e) Caging by four-finger

Fig. 2 Grasping a square object

Table 1 Robustness of each grasp pattern

\begin{tabular}{|l|c|} 
Position & robustness \\
\hline Fig. 1 (a) & 24.23 \\
Fig. 1 (b) & 10.17 \\
Fig. 2 (a) & 10.17 \\
Fig. 2 (b) & 12.99 \\
Fig. 2 (c) & 12.99 \\
Fig. 2 (d) & 12.99 \\
Fig. 2 (e) & 52.61
\end{tabular}

\section{3 くびれ形状物体のケージング把持}

二指平行グリッパによってくびれ形状物体を把持した場合 [10] （Fig. 3）を考え，ロバスト性解析の計算例を示す．ここで，平 行グリッパと物体は二点で接触するものとする．各パラメータ は以下のように設定する.

共通パラメータ

$$
\tau_{\max }=40.0, \quad \boldsymbol{J}=\left[\begin{array}{cc}
-0.5 & 0 \\
0 & 0 \\
-0.5 & 0 \\
0 & 0 \\
0 & 0.5 \\
0 & 0 \\
0 & 0.5 \\
0 & 0
\end{array}\right]
$$

Fig. 3 (a) のパラメータ

$$
\begin{gathered}
\boldsymbol{p}_{11}=\boldsymbol{p}_{1}=\left[\begin{array}{c}
2.0 \\
0.075
\end{array}\right], \boldsymbol{p}_{12}=\boldsymbol{p}_{2}=\left[\begin{array}{c}
2.0 \\
-0.075
\end{array}\right], \\
\boldsymbol{p}_{21}=\boldsymbol{p}_{3}=\left[\begin{array}{c}
-2.0 \\
0.075
\end{array}\right], \boldsymbol{p}_{22}=\boldsymbol{p}_{4}=\left[\begin{array}{c}
-2.0 \\
-0.075
\end{array}\right], \\
\boldsymbol{T}_{1}=\left[\begin{array}{l}
0 \\
1
\end{array}\right], \boldsymbol{T}_{2}=\left[\begin{array}{c}
0 \\
-1
\end{array}\right], \boldsymbol{T}_{3}=\left[\begin{array}{l}
0 \\
1
\end{array}\right], \boldsymbol{T}_{4}=\left[\begin{array}{c}
0 \\
-1
\end{array}\right],
\end{gathered}
$$




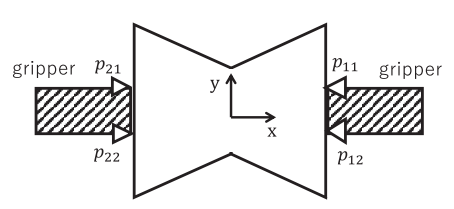

(a) Pinching parallel to the side

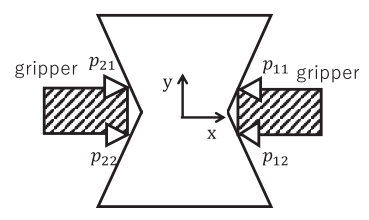

(b) Pinching a neck-part

Fig. 3 Grasping an object like an hourglass

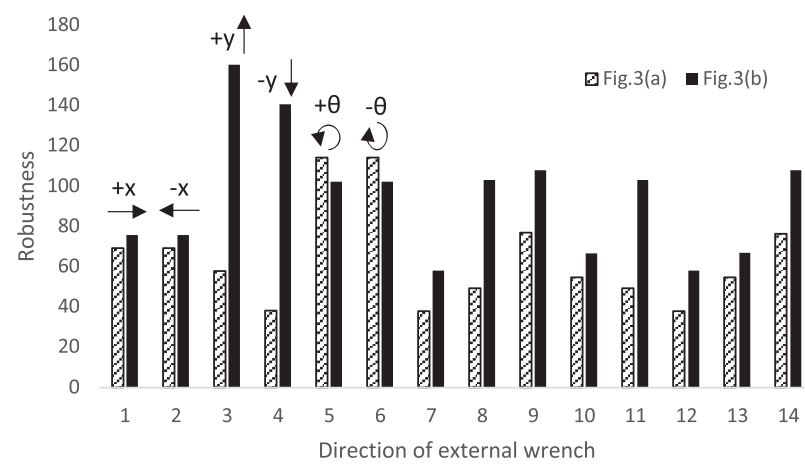

Fig. 4 Robustness against external wrench in each direction (a case of grasping the object like an hourglass). Arrows above the bars indicate each direction of external wrench

$\boldsymbol{N}_{1}=\left[\begin{array}{c}-1 \\ 0\end{array}\right], \boldsymbol{N}_{2}=\left[\begin{array}{c}-1 \\ 0\end{array}\right], \boldsymbol{N}_{3}=\left[\begin{array}{l}1 \\ 0\end{array}\right], \boldsymbol{N}_{4}=\left[\begin{array}{l}1 \\ 0\end{array}\right]$

Fig. 3 (b) のパラメータ

$$
\begin{gathered}
\boldsymbol{p}_{11}=\boldsymbol{p}_{1}=\left[\begin{array}{c}
1.038 \\
0.075
\end{array}\right], \boldsymbol{p}_{12}=\boldsymbol{p}_{2}=\left[\begin{array}{c}
1.038 \\
-0.075
\end{array}\right], \\
\boldsymbol{p}_{21}=\boldsymbol{p}_{3}=\left[\begin{array}{c}
-1.038 \\
0.075
\end{array}\right], \boldsymbol{p}_{22}=\boldsymbol{p}_{4}=\left[\begin{array}{c}
-1.038 \\
-0.075
\end{array}\right], \\
\boldsymbol{T}_{1}=\left[\begin{array}{c}
1 / \sqrt{5} \\
2 / \sqrt{5}
\end{array}\right], \boldsymbol{T}_{2}=\left[\begin{array}{c}
1 / \sqrt{5} \\
-2 / \sqrt{5}
\end{array}\right], \\
\boldsymbol{T}_{3}=\left[\begin{array}{c}
-1 / \sqrt{5} \\
2 / \sqrt{5}
\end{array}\right], \boldsymbol{T}_{4}=\left[\begin{array}{c}
-1 / \sqrt{5} \\
-2 / \sqrt{5}
\end{array}\right], \\
\boldsymbol{N}_{1}=\left[\begin{array}{c}
-2 / \sqrt{5} \\
1 / \sqrt{5}
\end{array}\right], \boldsymbol{N}_{2}=\left[\begin{array}{c}
-2 / \sqrt{5} \\
-1 / \sqrt{5}
\end{array}\right], \\
\boldsymbol{N}_{3}=\left[\begin{array}{c}
2 / \sqrt{5} \\
1 / \sqrt{5}
\end{array}\right], \boldsymbol{N}_{4}=\left[\begin{array}{c}
2 / \sqrt{5} \\
-1 / \sqrt{5}
\end{array}\right] .
\end{gathered}
$$

解析の結果，Fig. $3(\mathrm{a})$ でのロバスト性の最小值は 37.83 であ り, Fig. 3 (b) でのロバスト性の最小值は 58.23 であったことか ら, Fig. 3 (b) の把持姿勢のほうがより堅い拘束であるといえる. 外力の方向ごとのロバスト性の評価值を Fig. 4 に示す. 外力の 方向ごとに比較した場合においても多くのパターンでFig. 3 (b) のロバスト性がより高いことが分かった。この結果は二次曲面 を持つ対象物を表面が柔軟なグリッパで把持した宇都ら [10] の 結果と同様に，くびれ部分の把握をするほうが把持安定性が高 いことを示している．本論文では対象物およびロボットの表面 の変形を伴わない剛体モデルで, 多点接触で近似する場合でも 解析でき，そのため，線形計画問題を適用できる.

\section{$3.4 \mathrm{~T}$ 型物体のケージング把持}

次に $\mathrm{T}$ 型物体を把握した例 $($ Fig. 5) で解析を行う。接触点 は一つの接触面あたり一点で近似する。

共通パラメータ

$$
\tau_{\max }=40.0, \quad \boldsymbol{J}=\left[\begin{array}{cc}
-1.0 & 0 \\
0 & 0 \\
0 & 0 \\
0 & 0 \\
0 & 1.0 \\
0 & 0 \\
0 & 0 \\
0 & 0
\end{array}\right]
$$

Fig. 5 (a) のパラメータ

$$
\boldsymbol{p}_{11}=\boldsymbol{p}_{1}=\left[\begin{array}{c}
1.0 \\
0.075
\end{array}\right], \boldsymbol{p}_{12}=\boldsymbol{p}_{2}=\left[\begin{array}{c}
1.075 \\
0
\end{array}\right],
$$
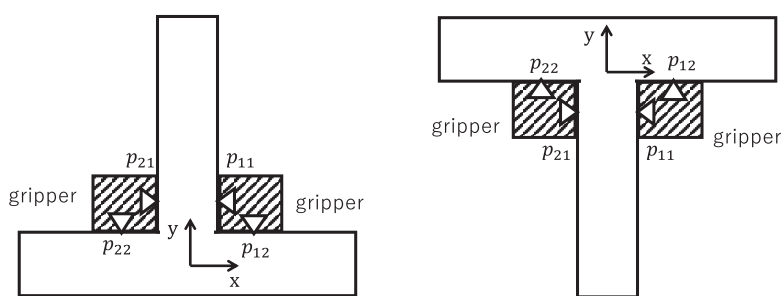

(a) Pinching the upside-down (b) Pinching the T-shaped object T-shaped object

Fig. 5 Grasping a T-shaped object

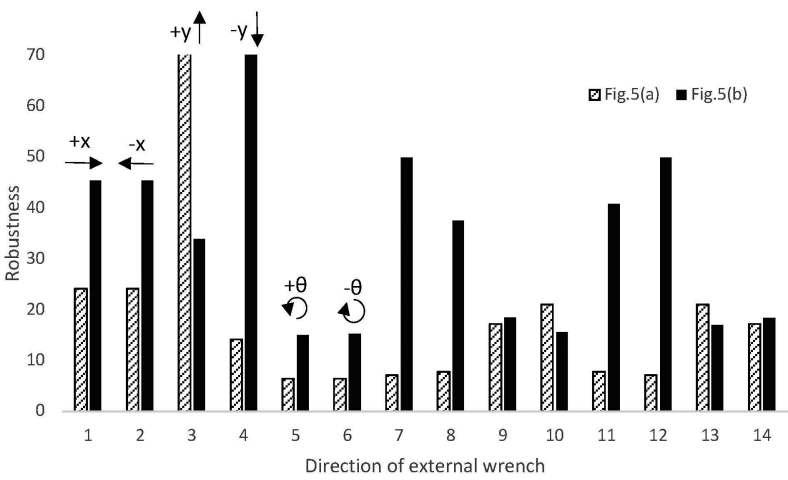

Fig. 6 Robustness against external wrench in each direction (a case of grasping the T-shaped object). Arrows above the bars indicate each direction of external wrench

$$
\begin{gathered}
\boldsymbol{p}_{21}=\boldsymbol{p}_{3}=\left[\begin{array}{c}
-1.0 \\
0.075
\end{array}\right], \boldsymbol{p}_{22}=\boldsymbol{p}_{4}=\left[\begin{array}{c}
-1.075 \\
0
\end{array}\right], \\
\boldsymbol{T}_{1}=\left[\begin{array}{l}
0 \\
1
\end{array}\right], \boldsymbol{T}_{2}=\left[\begin{array}{l}
1 \\
0
\end{array}\right], \boldsymbol{T}_{3}=\left[\begin{array}{l}
0 \\
1
\end{array}\right], \boldsymbol{T}_{4}=\left[\begin{array}{l}
1 \\
0
\end{array}\right], \\
\boldsymbol{N}_{1}=\left[\begin{array}{c}
-1 \\
0
\end{array}\right], \boldsymbol{N}_{2}=\left[\begin{array}{c}
0 \\
-1
\end{array}\right], \boldsymbol{N}_{3}=\left[\begin{array}{l}
1 \\
0
\end{array}\right], \boldsymbol{N}_{4}=\left[\begin{array}{c}
0 \\
-1
\end{array}\right] .
\end{gathered}
$$

Fig. 5 (b) のパラメータ

$$
\begin{gathered}
\boldsymbol{p}_{11}=\boldsymbol{p}_{1}=\left[\begin{array}{c}
1.0 \\
-0.075
\end{array}\right], \boldsymbol{p}_{12}=\boldsymbol{p}_{2}=\left[\begin{array}{c}
1.075 \\
0
\end{array}\right], \\
\boldsymbol{p}_{21}=\boldsymbol{p}_{3}=\left[\begin{array}{c}
-1.0 \\
-0.075
\end{array}\right], \boldsymbol{p}_{22}=\boldsymbol{p}_{4}=\left[\begin{array}{c}
-1.075 \\
0
\end{array}\right], \\
\boldsymbol{T}_{1}=\left[\begin{array}{l}
0 \\
1
\end{array}\right], \boldsymbol{T}_{2}=\left[\begin{array}{l}
1 \\
0
\end{array}\right], \boldsymbol{T}_{3}=\left[\begin{array}{l}
0 \\
1
\end{array}\right], \boldsymbol{T}_{4}=\left[\begin{array}{l}
1 \\
0
\end{array}\right], \\
\boldsymbol{N}_{1}=\left[\begin{array}{c}
-1 \\
0
\end{array}\right], \boldsymbol{N}_{2}=\left[\begin{array}{l}
0 \\
1
\end{array}\right], \boldsymbol{N}_{3}=\left[\begin{array}{l}
1 \\
0
\end{array}\right], \boldsymbol{N}_{4}=\left[\begin{array}{l}
0 \\
1
\end{array}\right] .
\end{gathered}
$$

解析の結果, Fig. 5 (a) でのロバスト性の最小值は 6.42 であ り, Fig. 5 (b) でのロバスト性の最小值は 15.08 であったことか ら, Fig. 5 (b) のグリッパの配置がより堅い拘束であるといえる. また, 外力の方向ごとのロバスト性の違いを Fig. 6 に示す. ロバ スト性の総和を取る際, Fig. 5 (a) では $+y$ 方向 $\left(\boldsymbol{l}_{3}\right)$, Fig. 5 (b) では $-y$ 方向 $\left(\boldsymbol{l}_{4}\right)$ に対するロバスト性が無限大を示しているの でこれを省いて計算する. Fig. 5 (a) では 181.7, Fig. 5 (b) で は 402.4 となった.

\section{4. 結 果 の考 察}

正方形物体とくびれ形状物体, $\mathrm{T}$ 型物体に対して接触点を与 え，ロバスト性解析を行った．正方形物体の把持では Table 1 の 結果から，Fig. 1 (b) と Fig. 2 (a) は同一の評価值であった. 正 方形物体の $+y$ 方向に指を配置するとその方向のロバスト性は向 上するが，ロバスト性の最小值には影響しないため，この指配置 の重要度は低いことが分かる. また, Fig. 2 (b) と Fig. 2 (c) を比 較した場合においても同様の結果が得られたことから, Fig. 1 (a) の指配置のように重力に対抗できる接触力が発生できる $-y$ 方 向に指を配置することの重要度が高いことが分かった。

くびれ形状物体の把持ではくびれ部分を掴む例 (Fig. 3(b)) が 
ケージングの拘束性能が高いことを示したが, これは文献 [10] [11] のくびれ部分の把持と同等であり, 本論文の結果と同じく force closure に基づく安定性評価においても高い安定性を示している 把握形態である。このことからくびれ部分の把持は力学的, 幾 何学的両方からの観点で拘束性能が高く, 信頼性の高い把握形 態であることがいえる。

$\mathrm{T}$ 型物体を把持した例では，物体と接触点の相対位置は変 化していないが物体の姿勢による拘束性能の違いがみられた. Fig. 5 (b) の姿勢が拘束性能が高い把持姿勢といえることを示し た.この理由として, 既知の外力として $-y$ 方向の重力が働い ており，これによって Fig. 5 (b) の姿勢では接触点が物体を受動 的に拘束しているからである。このことから，重力を利用して 物体を受動的に拘束できるような把持姿勢を考えることで，よ り高い評価值が獲得できると考える。

\section{5. おわりに}

本論文ではマニピュレーションの接触力解析およびロバスト 性の評価指標を用いて，ケージング把持の物体拘束性能を力学 モデルを導入した解析によって評価した。ロボットによる囲い 込みが不完全で，物体が抜け出す可能性のある幾何学的拘束で は，重力やロボット指からの接触力などの力学条件により，物 体拘束の性能が変わる. 本論文では把持やマニピュレーション のロバスト性の評価指標を応用し，様々な把持姿勢において指 配置が対象物の幾何学的拘束に与える効果を評価できることを 示した. 数值計算例においては三種類の対象物について，複数 の把持姿勢のロバスト性を計算し，力学条件も考慮したケージ ングの拘束性能を評価した。ここでは，位置制御指の把持によ る過大な内力の発生を考慮して便宜上，すべてのロボット指を ハイブリッド制御するものとして扱った。この解析結果から, 幾何学的拘束を考慮した把持が力学的にも拘束性能が高いこと, 力学条件を考慮したパーシャルなケージングの拘束性能を定量 的に評価できることを示した。

本手法は三次元空間の問題にも適用できる $[12]$. 今後はより 複雑な形状の物体やその把握形態について議論すること, ロボッ トによる把持計画などへ適用することが期待される.

謝 辞 本研究は JSPS 科研費 JP17H04669 の助成を受けた
ものです。

\section{参 考 文 献}

[1] E. Rimon and A. Blake: "Caging Planar Bodies by OneParameter Two-Fingered Gripping Systems," The Int. J. of Robotics Research, vol.18, issue 3, pp.299-318, 1999.

[2] S. Makita and W. Wan: "A survey of robotic caging and its applications," Advanced Robotics, vol.31, issue 19-20, pp.1071$1085,2017$.

[ 3 ] T. Makapunyo, T. Phoka, P. Pipattanasomporn, N. Niparnan and A. Sudsang: "Measurement framework of partial cage quality," Proc. of IEEE Int. Conf. on Robotics and Biomimetics, pp.1812-1816, 2012.

[ 4] T. Makapunyo, T. Phoka, P. Pipattanasomporn, N. Niparnan and A. Sudsang: "Measurement framework of partial cage quality based on probabilistic motion planning," Proc. of Int. Conf. on Robotics and Automation, pp.1574-1579, 2013.

[5] J. Mahler, F.T. Pokorny, Z. Mccarthy, A.F.v.d. Stappen, K. Goldberg: "Energy- bounded caging: formal definition and 2D energy lower bound algorithm based on weighted alpha shapes," IEEE Robotics and Automation Letter, vol.1, no.1, pp.508-515, 2016.

[6] 小俣, 永田：“多指ハンドによるパワーグラスプの力学的特性”, 日本 ロボット学会誌, vol.13, no.4, pp.525-531, 1995.

[7] 槇田, 後藤, 前田：“ロボットマニピュレーションにおける接触力の 準静力学的解析 一定式化とそのグラスプレス・マニピュレーション のロバスト性評価への応用—”，日本ロボット学会誌，vol.31, no.10, pp.1009-1018, 2013.

[ 8 ] C. Mladenova: "Group theory in the problems of modeling and control of multi-body systems," J. of Geometry and Symmetry in Physics, vol.8, pp.17-121, 2006.

[9] Y. Maeda and T. Arai: "A quantitative stability measure for graspless manipulation," Proc. of IEEE Int. Conf. on Robotics and Automation, pp.2473-2478, 2002.

[10] 宇都, 辻, 原田, 田原, 長谷川, 倉爪：“区分的な二次曲面近似に基づく 把持姿勢候補の生成”, ロボティクス・シンポジア予稿集, pp.225-230, 2013.

[11] T. Tsuji, S. Uto, K. Harada, R. Kurazume, T. Hasegawa and K. Morooka: "Grasp planning for constricted parts of objects approximated with quadric surfaces," IEEE/RSJ Int. Conf. on Intelligent Robots and Systems, pp.2447-2453, 2014.

[12] S. Makita and K. Makihara: "Homogeneous Quantitative Measure of Caging Grasps with both Geometrical and Mechanical Constraints," The Int. Conf. on Control, Automation and Systems, pp.311-316, 2019.

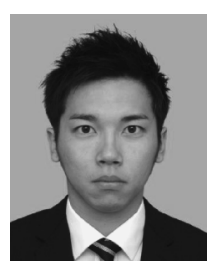

牧原昂志（Koshi Makihara）

2019 年筑波大学大学院システム情報工学研究科知能 機能システム専攻博士前期課程在学. マニピュレー ションの研究に従事.（日本ロボット学会学生会員）

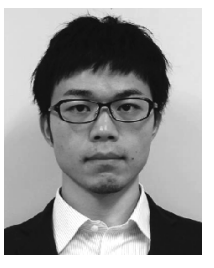

槇田 諭（Satoshi Makita）

2010 年横浜国立大学大学院工学府システム統合工 学専攻博士課程後期修了. 同年佐世保工業高等専門 学校電子制御工学科助教, 2012 年同講師, 2019 年同 准教授. 2020 年福岡工業大学工学部知能機械工学 科助教.マニピュレーション, 精密部品組立装置, 手 指のバイオメカニクスの研究に従事. IEEE ICRA 2013 Best Manipulation Paper Award Finalist に選出, IEEE RAS Japan Chapter Young Award（IEEE/RSJ IROS 2008）を受賞. 日本機械学会, 計測自動制御学会, 日本義肢装具学会, IEEE の会員. 博士 (工学).
(日本ロボット学会正会員) 